\title{
A large scale survey of trace metal levels in coastal waters of the Western Mediterranean basin using caged mussels (Mytilus galloprovincialis)
}

\author{
José Benedicto $^{\mathrm{a}}$, Bruno Andral ${ }^{\mathrm{b}}$, Concepción Martínez-Gómez ${ }^{\mathrm{a}}$, Carlos Guitart ${ }^{\mathrm{a}, *}$, Salud Deudero ${ }^{\mathrm{a}, \mathrm{c}}$, \\ Alessandro Cento ${ }^{d}$, Alfonso Scarpato ${ }^{\mathrm{e}}$, Josep Caixach $^{\dagger}$, Samir Benbrahim $^{\mathrm{g}}$, Lassaad Chouba ${ }^{\mathrm{h}}$, \\ Mostefa Boulahdid' and François Galgani ${ }^{b}$
}

\footnotetext{
${ }^{a}$ Instituto Español de Oceanografía (IEO), Centro Oceanográfico de Murcia, c/Varadero 1, 30740 San Pedro del Pinatar, Murcia, Spain

${ }^{\mathrm{b}}$ IFREMER, Laboratoire Environment Resource Provence Azur Corse, BP 330, 83507 La Seyne sur Mer Cedex, France

c Laboratorio de Biología Marina and GOI-IMEDEA (CSIC-UIB), Guillén Colom, Campus Universitari, Ctra. de Valldemossa, km 7.5, 07122 Palma de Mallorca, Spain

d Parco Scientifico e Tecnologico della Sicilia (PSTS), Z.I. Blocco Palma, s.s. G. Agnelli Angolo, 95030 Catania, Sicilia, Italy

e Instituto Superiore per la Protezione e la Ricerca Ambientale (ISPRA), Via di Casalotti 300, 00166 Rome, Italy

${ }^{f}$ Instituto de Diagnóstico Ambiental y Estudios del Agua (IDAEA-CSIC), c/Jordi Girona 18-26, 08034 Barcelona, Spain

${ }^{g}$ Institut National de Recherche Halieutique (INRH), 2 rue de Tiznit, Casablanca 04, Morocco

${ }^{\mathrm{h}}$ Institut National des Sciences et Technologies de la Mer (INSTM), 28, rue du 2 mars 1934, 2025 Salammbô, Tunisie

'Institut National des Sciences de la Mer et des l'Aménagement du littoral (ISMAL), Bois des cars, BP 19, 16320, Alger, Algeria
}

*: Corresponding author : Carlos Guitart, email address : carlos.guitart@mu.ieo.es

\begin{abstract}
:
A large scale study of trace metal contamination $(\mathrm{Hg}, \mathrm{Cd}, \mathrm{Pb}$ and $\mathrm{Ni}$ ) by means of caged mussels Mytilus galloprovincialis was undertaken along the coastal waters of the Western Mediterranean Sea within the context of the MYTILOS project. Individual mussels from an homogeneous population (shell size $50 \pm 5 \mathrm{~mm}$ ) obtained from an aquaculture farm were consecutively caged and deployed at 123 sites located in the Alborán, North-Western, South-Western and Tyrrhenian sub-basins for 12 weeks (April-July) in 2004, 2005 and 2006. After cage recoveries, both the metal content in the whole mussel tissue and the allometric parameters were measured. Statistical analysis of the datasets showed significant differences in concentrations between sub-basins for some metals and mussel condition index $(\mathrm{Cl})$. Linear regression models coupled to the $\mathrm{Cl}$ were revisited for the data adjustment of certain trace metals $(\mathrm{Hg}, \mathrm{Cd}$ and $\mathrm{Ni})$, and four level categories were statistically derived to facilitate interregional comparison. Seawater masses surrounding coastal areas impacted by run-off from land mineralised coasts and industrial activities displayed the highest concentration ranges ( $\mathrm{Hg}: 0.15-0.31$ $\mathrm{mg} / \mathrm{Kg} \mathrm{dw}$.; Cd: 1.97-2.11; Ni: 2.18-3.20 and Pb:3.1-3.8), although the levels obtained in most of the sites fitted within moderate or low categories, and they could be considered as baseline concentrations. However, few sites considered little-influenced by human activities, at present, showed high concentrations of $\mathrm{Cd}, \mathrm{Ni}$ and $\mathrm{Pb}$, which constitute new areas of concern. Overall, the use of active biomonitoring (ABM) approach allowed to investigate trace metal contamination in order to support policy makers in establishing a regional strategies (particularly, with regard to the European Marine Strategy Directive).
\end{abstract}

Keywords : trace metals, caged mussel, condition index, Western Mediterranean, coastal waters, active biomonitoring 


\section{Introduction}

Trace metals occur naturally in the marine environment, but anthropogenic activity may lead to enhance natural concentrations, mainly in estuarine and coastal waters ${ }^{1}$. Although most of trace metals are essential to marine organisms they became toxic if a particular threshold is exceeded, which varies between taxa ${ }^{2}$. Trace metals could pose also a serious threat to human health because of their persistent occurrence and bioaccumulation capacity, which constitutes a potential risk to seafood and shellfish consumers ${ }^{3}$. These global concerns are heightened in the Mediterranean Sea due to its semi-enclosed nature (which can magnify the risks from exposure to contaminants such as metals), the complex geomorphology of its basins, and the variety of metal sources involved due to increasing urban, industrial and marine transport pressures ${ }^{4,5}$. Therefore the investigations on trace metals is a priority component in national and regional marine chemical contamination monitoring programmes all over the world, including the Mediterranean Sea ${ }^{6}$. These are also driven in Europe by the EU Water Framework Directive ${ }^{7}$ and the EU Marine Strategy Directive ${ }^{8}$ where those are listed as high-priority contaminants.

The use of indigenous mussels to monitor chemical contamination has been recommended by the MED POL Programme in the Mediterranean Sea, since the mussel-watch concept was proposed in the early $1970 \mathrm{~s}^{9}$, and as a result, several assessments of the state of pollution by trace metals using biota have been based on these datasets ${ }^{10}$. However, most of the studies were geographically restricted, despite geopolitical boundaries, to rocky shores where mussel beds can be found, leaving other relevant coastal water bodies outside the scope of these studies, as is the case of the coastal dilution zones (i.e. near-shore waters), where the dispersion of the trace metals take place. These limitations have made difficult to provide a simple and straightforward picture of the overall trace metal contamination based in passive biomonitoring studies.

Wild mussels (Mytilus sp.) have many monitoring advantages, the most important being they are able to concentrate trace metals and organic contaminants in their tissues with little metabolic transformation and provide a time integrated measurement of the bioavailable fraction in the surrounding seawaters ${ }^{11}$. However, inherent variability in metal uptake and depuration processes by mussels, due to biotic and abiotic factors, are important sources of variability and need some attention in order to compare datasets from mussels of different areas or regions ${ }^{12}$. For example, lead uptake rates by Mytilus edulis in different laboratory conditions shown lower uptake and loss rates in large mussels than in small mussels, as well as different uptake rates by individual organs ${ }^{13}$. Also attempts to model physiological processes in Mytilus $s p$. for mercury and lead have been investigated ${ }^{14}$. With regard to abiotic factors, it has also been shown a relationship between the salinity and temperature with the uptake of cadmium and zinc by Mytillus edulis ${ }^{15}$. Therefore, to control for the factors influenced by natural variability and to solve the scarcity of natural mussel stocks along the coasts, active biomonitoring (ABM) using caged mussels was introduced by different authors ${ }^{16,17,18,19,20}$. The ABM approach allows to use specimens of similar biological parameters (i.e. allometric) and to choose the location, depth and exposure period during the study. In the Western Mediterranean Sea, in recent years, this technique has been applied successfully in some specific areas ${ }^{18,19,21,22,23}$. However, there could be also drawbacks related to the experimental work when the ABM approach is used on a large geographical scale (e.g. the potential loss or damage of the deployed cages, mussel mortality, costs constrains, etc.). On the other hand, the potential for the changing environmental variables over large areas need to be taken into account, thus for trace metals the bioaccumulation factor depends both on the physiochemical 
characteristics of the surrounding waters (i.e. external factors) and the mussel physiological status (i.e. internal factors), the latter linked to the primary food production or trophic capacity of the environment ${ }^{24,25}$. Different approaches (i.e. data normalisation) have been reported to overcome the influence of the internal mussel physiology on metal concentrations, such as pollutant levels per condition index ${ }^{26}$, tissue growth ${ }^{27}$, lipid content ${ }^{28}$ or shell weight ${ }^{29}$. Recently, to overcome both limitations, samplers by diffusive gradients in thin films (DGT), are starting to be tested as an alternative to biomonitoring strategies ${ }^{19,30,31}$.

In this study, we examine the condition index coupled to regression models methodologies ${ }^{32,33}$, to a large scale biomonitoring study in the Western Mediterranean region for data normalisation. The datasets of mercury $(\mathrm{Hg})$, cadmium $(\mathrm{Cd})$, lead $(\mathrm{Pb})$ and nickel $(\mathrm{Ni})$ along the coastal dilution zone of land based contamination sources are considered in terms of their environmental significance, characteristic sources, and comparatively with datasets reported in caged mussels elsewhere in the world. As far as we know, we present the first assessment categories of trace metal levels in nearshore coastal waters to facilitate the interpretation and to allow the comparison between regions and the Western Mediterranean sub-basins (i.e. Alboran, Northwestern, Southwestern and Tyrrhenian). We assess whether metal concentrations show any significant spatial variation by using the same $A B M$ standardised approach for the whole Western Mediterranean.

\section{Materials and methods}

\subsection{Mussel caging, deployment and recovery}

The mussels (Mytilus galloprovincialis) were obtained from an aquaculture farm located in the Mediterranean French coast (Languedoc-Roussillon) and were placed in cages of polyethylene netting (dimensions $1 \mathrm{~m} \times 1 \mathrm{~m}$ with $1 \mathrm{~cm}$ mesh size) and deployed at 123 sites along the coast of the Western Mediterranean countries (Fig. 1; Supplementary material). Batches were made up with 200 mussels 18-24 months old of standardized shell size $(50 \pm 5 \mathrm{~mm})$ and sorted twice according to the height of the shell through 19$\mathrm{mm}$ mesh. Prior to deployment, the $3 \mathrm{~kg}$ samples were stored in cages mounted on PVC tubing and re-immersed for 10 days so they can re-cluster prior to transplantation and a sample was taken for reference (see Supplementary material). Cages were deployed over periods of 12 weeks in 2004, 2005 and 2006 (immersed in April and recovered in July). Every year, the caged mussels were deployed in a selected portion of the Mediterranean coast at approximately $6 \mathrm{~m}$ to $8 \mathrm{~m}$ below the sea surface (ranging from $10 \mathrm{~m}$ to $74 \mathrm{~m}$ depth) to cover the whole study area. To select the distribution of the deployments, we followed the division in four sub-basins for the Western Mediterranean region according to Jeftic (1990): Alborán (I), North-Western (II), SouthWestern (III) and Tyrrhenian (IV). Additional information on field experiments performed during the cruises has been reported elsewhere ${ }^{34,35}$.

\subsection{Sample treatment and chemical analysis}

A composite sample from mussel soft tissues ( $n=15$ individuals) from each site, to reduce the inter-individual variability, was processed aboard according to standardised procedures and stored at $-20^{\circ} \mathrm{C}$. Once in the laboratory, composite samples were lyophilised and homogenised using a ball mill made of agate. The allometric parameters (e.g. dry flesh weight, dry shell weight and length, width and height of the shell), as well as the survival percentage (ranging from $98 \%$ [Site 122 Cap des 3 
fourches] to $49 \%$ [Site 52, Reserve Marine du Cannes], mean: $77 \%$. SD: 12) were measured. The $\mathrm{Cl}$ was calculated on 10 individual specimens from each site as the ratio of the dry flesh weight to dry shell weight. Trace metal analyses were performed with approximately $0.5 \mathrm{~g}$ of freeze-dried mussel sample digested at $90{ }^{\circ} \mathrm{C}$ for 10 minutes and at $180{ }^{\circ} \mathrm{C}$ for other 60 minutes, using high pressure Teflon reactors and concentrated $\mathrm{HNO}_{3}$ in a microwave oven system. The concentrations of $\mathrm{Pb}, \mathrm{Cd}$ and $\mathrm{Ni}$ were determined by graphite furnace atomic absorption spectrophotometry with Zeeman background correction (AAS-ZGF) instrument (Perkin Elmer 4110-ZL). Total Hg was determined by atomic fluorescence using a reducing dissolution of $10 \% \mathrm{SnCl}_{2}$ in $6 \% \mathrm{v} / \mathrm{v}$ $\mathrm{HCl}$ (CV-AAS). The analytical and quality assurance was performed by IFREMER using certified reference materials, duplicate samples and procedural blanks. External validation of the analytical procedures is regularly assessed by participation in QUASIMEME (Quality Assurance of Information in Marine Environmental in Europe) interlaboratory exercises for trace metal analysis.

\subsection{Data treatment and statistical analysis}

Exploratory statistics (SPSS Software) was performed for the four regional Western Mediterranean sub-basins datasets (Alborán (I), North-Western (II), South-Western (III) and Tyrrhenian (IV)) and for the whole Western Mediterranean. Linear regression models were performed using the LTS regression function (S-Plus 6 Software), which allow to remove outliers and to calculate the parameters of the regression for each trace metal (see Supplementary Material). Trace metals with a correlation coefficient higher than $50 \%$ were adjusted to a mean $\mathrm{Cl}$ following the procedure by Andral et al. ${ }^{33}$. Adjusted and/or raw concentrations for each metal were log-transformed (to ensure a normal distribution; Kolmogorov-Smirnov test). Log-transformed datasets were used to perform a one-way ANOVA to study differences in metal concentrations between sub-basins (homogeneity of variances was checked using Levene's test). We tested the null hypothesis that the error variance of the dependent variable (i.e. concentration) is equal across groups (i.e. sub-basins). When parametric requirements were not fulfilled in the groups under consideration the Kruskall-Wallis (K-W) test was applied. If significant differences were detected between sub-basins, the Tukey's b or Tamhane's T2 post-hoc tests were applied for pair-wise comparison. A setting of $\alpha=0.01$ was used with parametric analyses to compensate for the increased likelihood of type I error caused by any imbalance design in the study (i.e. different number of measurements for each subbasin).

Metal level categories for the caged mussels datasets were developed using a modification of O'Connor's statistical procedure ${ }^{36}$ to facilitate the assessment of the results in the whole Western Mediterranean Sea: Mean (X) and standard deviation (SD) of the log-normal frequency distribution curves for each metal dataset were used to statistically derive four categories: a "very high concentration" category where data was equal or more than [values $\geq X+2$ SD]; a "high concentration" category which included values higher than the mean plus one standard deviation $[\geq X+1$ SD to $<X+2 S D$ ]; a "moderate concentration" category was defined as [ $\geq X-1$ SD to $<X+1 S D$ ]; and finally, a "low concentration" category to include values less than the mean minus one standard deviation [values $<\mathrm{X}-1 \mathrm{SD}$ ]. 


\section{Results and Discussion}

\subsection{Regression models and condition index adjustment}

The $\mathrm{Cl}$ values measured in the Western Mediterranean basin ranged from 0.06 to 0.22 [0.103-0.117; 95\% confidence interval for the mean $(\mathrm{CIM})]$. The results shown significant differences in $\mathrm{Cl}$ values within mussels deployed in the four sub-basins, despite they were immersed during the same time and seasonal period, although in different years (Kruskall Wallis test; Tanhane T2 pos-hoc test; $p<0.01$ ). The $C l$ values were significantly higher in western sub-basins (Alborán (I), North-Western (II)) than in the eastern ones (South-Western (III) and Tyrrhenian (IV)). To allow comparisons and minimise the influence of internal factors (e.g. mussel growth rates) on metal concentrations, we adjusted metal concentrations to a mean $\mathrm{Cl}^{33}$ (equivalent to standard $\mathrm{Cl}$ for a theoretical mussel representing the whole population), for $\mathrm{Cd}, \mathrm{Hg}$ and $\mathrm{Ni}$ which showed concentrations inversely proportional to the $\mathrm{Cl}$ (see Supplementary Material).

Firstly, the linear regression models were determined for trace metals against the $1 / \mathrm{Cl}$ dataset according:

$$
\mathrm{C}_{\text {true }}=\mathrm{m}_{\text {metal }} *\left[1 / \mathrm{Cl}_{\text {true }}\right]+\mathrm{b}
$$

In addition, the mean $\mathrm{Cl}$ ratio (0.11) was calculated. According to the correlation coefficient $\mathrm{R}^{2}$ of the models obtained and its significance level, more than $80 \%$ of the $\mathrm{Cd}$ and $\mathrm{Hg}$ concentrations and a $50 \%$ of the Ni concentrations might be explained by the $\mathrm{Cl}$ of the mussels. In the case of $\mathrm{Pb}$ concentrations, the influence of $\mathrm{Cl}$ was not relevant. Secondly, known the slope (i.e. $m_{\text {metal }}$ ) for each metal dataset and a point (a pair metal concentration and $\mathrm{Cl}$ ), we adjusted the metal concentration datasets (assuming equal slopes) with the mean $\mathrm{Cl}$ by using the point-slope form of a linear equation $\left[\mathrm{Y}-\mathrm{Y}_{1}=\mathrm{m}\left(\mathrm{X}-\mathrm{X}_{1}\right)\right]$, as:

$$
\mathrm{C}_{\text {adjusted }}=\mathrm{C}_{\text {true }}+\mathrm{m}_{\text {metal }}\left(\mathrm{Cl}_{\text {mean }}-\mathrm{Cl}_{\text {true }}\right)
$$

The raw and adjusted metal concentrations by site are provided in Figure 2. Adjusted data for $\mathrm{Cd}$ and $\mathrm{Hg}$ shows a more balanced dataset to compare the different subbasins in a large scale study area. For example, non-adjusted $\mathrm{Cd}$ concentrations (i.e. true concentrations) in the Balearic Islands showed higher values than the SE Spain, NE Spain, France and Italian Peninsula. This could be interpreted as a contaminant mass concentration effect due to the modest mussel growth rate in Balearic Islands, thus there are clear differences in the tropic conditions between these regions. Therefore, after the adjustment to a mean $\mathrm{Cl}$, the $\mathrm{Cd}$ concentrations in Balearic Islands decreased whilst the areas located in continental coast increased with respect to the true values, in this case, due to a mass dilution effect. However, the adjusted Cd concentrations in Balearic Islands still comparable to those in the SE Spain. The effect of the adjustment for $\mathrm{Hg}$ and $\mathrm{Ni}$ is not as pronounced as for $\mathrm{Cd}$, despite the same pattern can be observed, and was negligible for $\mathrm{Pb}$ values, because correlation exists for some metals to some extent, in accordance with previous research ${ }^{32,33}$. The adjustment methodology through $\mathrm{Cl}$ assumes that each mussel, including those which showed highest concentrations (i.e. outliers) have the same physiological behaviour without regard, for example, to the effects that high concentrations of metal might have in the mussel physiology (i.e. equal slopes assumption), as well as homogeneous external factors (e.g. temperature, salinity). In addition, the $\mathrm{Cl}$ neither change uniformly nor equally modulates the metal concentrations in organisms, on the contrary, it changes temporally as described by Borchart et al. ${ }^{32}$, as well as spatially, as demonstrated by our statistical analysis. This variability should be considered to 
interpret both spatial and temporal trends of metal pollution when using an adjustment model in the context of a large scale biomonitoring approach. In conclusion, data adjustment through linear regression models using the $\mathrm{Cl}$ allow to compare regions pseudo-quantitatively rather than qualitatively (i.e. non-adjusted) in a large scale because differences are partly balanced but not eliminated (Figure 2),. However, adjusted datasets could be difficult to compare with existing datasets compiled without adjustments (i.e. true measured values), as a result of outstanding corrections to data. Therefore, a scientific consensus and further research would be necessary in order to establish a common approach for data analysis resulting from biomonitoring programs world-wide. From a human health perspective, the true concentration datasets (see Supplementary Material) would be more useful than adjusted concentrations for further parallel investigations.

\subsection{Geographical differences in trace metal concentrations}

The $\mathrm{Pb}$ concentrations recorded in the Western Mediterranean basin were generally categorized as "moderate levels" (Fig. 3A) for the $83 \%$ of sites (CIM $=1.23-1.61 \mathrm{mg}$ $\mathrm{kg}^{-1} \mathrm{dw}$ ). Significant differences in raw $\mathrm{Pb}$ concentrations were found between subbasins (Kruskall-Wallis test; $p=0.029$ ). Mean $\mathrm{Pb}$ concentrations were lower in NorthWestern (II) and Tyrrhenian (IV) sub-basins than in Alboran (I) and South-Western (III) basins. Figure $3 \mathrm{~A}$ shown the highest concentration of $\mathrm{Pb}$ (ranging from 3.1 to 8.3 $\mathrm{mg} / \mathrm{Kg} \mathrm{d.w}$ ) found in mussels from Portoscuso and Portoferraio in Italy [site No. 99 and No. 73, respectively] and from three sites located along the SE coast of Spain: Cabo del Agua [site No. 11], El Portús [site No. 10] and Portmán [site No. 12]. The Pb dataset shown scattered "high levels" of $\mathrm{Pb}$ along the coast of the Iberian Peninsula (Llobregat river [site No. 35] and Cabo de Palos [site No. 13]); the coast of the Balearic Islands (Palma de Mallorca [site No. 21], Santa Eulalia [site No. 19] and Cala Trebeluja [site No. 28]); the south coast of France (Huveaune [site No. 47]); the northern coast of Italy (Zinola [Site No. 65]; the coast of Sardinia (Oristano and Porto Torres [site No. 100 and 101, respectively]; and the coast of Morocco (Nador [site No. 119]). The sites located along the coast of Italian Peninsula, Sicily, Tunisia and Algeria were categorized as "moderate levels".

Adjusted $\mathrm{Cd}$ concentrations ( $\mathrm{CIM}=1.29-1.37 \mathrm{mg} \mathrm{kg}^{-1} \mathrm{dw}$ ) were categorized as "moderate levels" and "low levels" (for the 69\% and 15\% of the sites, respectively; Figure 3B). Mean adjusted Cd value in Alborán sub-basin (I) was significantly higher than in the rest of sub-basins (1-way ANOVA, $p=0.000$; Tukey b post-hoc test, $p<$ 0.01). Some "very high" values (ranging from 1.97 to $2.11 \mathrm{mg} / \mathrm{Kg} \mathrm{d.w.;} \mathrm{adjusted} \mathrm{data)}$ were measured along the coast of Spain (Águilas [site No. 9], Adra [site No. 6], Mahón [site No. 29]) and near Sicily (Ustica [site No. 94]). Many of the "high levels" of Cd were recorded at sites along the south and south-eastern coast of Spain (Torrox [Site No. 5], Cabo de Gata [site No. 8], Almería [site No. 7], Cabo del Agua [site No. 11] and El Portús [site No. 10]); the coast of Balearic Islands (Cala Trebeluja [site No. 28], Fornells [site No. 30] and Santa Eulalia [site No. 19]) and Cabrera [site No. 22]); on the coast of Morocco (Cap des Trois Forches [site No. 122]); and at few sites along the coasts of Italy (Piombino [site No. 72]), Sardinia (Porto Torres [site 101] and Portoscuso [site No. 99]), Filicudi island [site No. 91] and in a site of France (Nice [site No. 53]).

Adjusted $\mathrm{Hg}$ concentrations ( $\mathrm{CIM}=0.09-0.10 \mathrm{mg} \mathrm{kg}^{-1} \mathrm{dw}$ ) showed (Figure 3C) a predominance of moderate levels for the $88 \%$ of the sites along the Western Mediterranean basin. Significant differences were found between sub-basins (K-W test, $p=0.003)$. The highest concentrations were found in those sites located in SouthWestern (III) sub-basin, though significant differences were only demonstrated between 
the Tyrrhenian sub-basin (IV) and Northwestern sub-basin (II) (post-hoc Tamhane test, $\mathrm{p}=0.002$ ). Very high $\mathrm{Hg}$ concentrations (ranging from 0.15 to $0.31 \mathrm{mg} / \mathrm{kg} \mathrm{dw}$; adjusted data) were measured at five scattered sites along the Western Mediterranean basin (Portoscuso [site No. 99], Palerme [site No. 93] and Maddalena Island [site No. 102] in Italy; Skikda in Algeria [site No. 113] and El Portús [site No. 10] in Spain). There was a predominance of high $\mathrm{Hg}$ values at Algiers Bay [Sites No. 117 and 118], along the north-west Italian peninsula (Montalto di Castro [site No. 77], Piombino [site No. 72], Portoferraio [site No. 73]) and in the French coast at Hyeres ouest [site No. 50].

Adjusted $\mathrm{Ni}$ concentrations $\left(\mathrm{CIM}=0.97-1.14 \mathrm{mg} \mathrm{kg}^{-1} \mathrm{dw}\right.$ ) were categorized as moderate for the $82 \%$ of the sites and there were no significant differences between the sub-basins of the Western Mediterranean Sea (1-way ANOVA, $p=0.817$ ). The spatial distribution clearly showed the highest $\mathrm{Ni}$ values along the North African coastline (Figure 3D). Ni levels categorized as "very high" were measured in 5\% of the sites (ranging from 2.18 to 3.20; adjusted data): Tunisia (Tabarka [site No. 111] and La Galite [site No. 110]); Algeria (Skikda [site No. 113], Zhour Oued [site No. 114], Orán [site No. 119]); and Morocco (Nador [site No. 120]). "High values" of Ni were found at the Gulf of Tunis (Sidi Daoud [site No. 105], Korbous [site No. 106], Rades [site No. 107] and Sidi Ali [site No. 108]); Algeria (Annaba [site No. 112]); along the north coast of the Italian peninsula (Livorno [site No. 71], Cornigliano [site No. 67] and Palmarola [site No. 81]); Sardinia (Porto Torres [site No. 101]), and France (Rhone [site No. 46]).

\subsection{Major land based, river discharges and industrial sources of metal pollution in the Western Mediterranean Sea}

Two sites, El Portús [site No. 10] in Spain and Portoscuso [site No. 99] in Sardinia Island (Italy), both in the vicinity of large industrial areas, commercial harbours and Zn$\mathrm{Pb}$ mining districts, differ from the rest of the Mediterranean sites as they shown the highest levels of $\mathrm{Pb}$ and $\mathrm{Hg}$ as well as high concentration of $\mathrm{Cd}$. Our results confirms that run-off from the old mines in the SE coast of Spain (closed in the nineties) is still one of the major land based sources of trace metals and have an outstanding impact on the environmental geochemistry of coastal areas of the Western Mediterranean sea as was earlier reported ${ }^{37,}{ }^{38}$. High levels of $\mathrm{Cd}$ and $\mathrm{Hg}$ in the seagrass Posidonia oceanica from El Portús ${ }^{39}$ and extreme levels of $\mathrm{Cd}, \mathrm{Pb}$ and $\mathrm{Hg}$ in resident mussels have been reported in the surrounding areas ${ }^{40}$. El Portús [site No. 10], is influenced by a major navy base, the industrial complex of Escombreras, and the Sierra de Cartagena-La Union mining district. We also found consistent high levels of $\mathrm{Pb}$ in Portmán [site No. 12] and Cabo del Agua [site No. 11], whereas high levels of Cd were found in Adra [site No. 6], Almería [site No. 7], Cabo de Gata [site No. 8] and Águilas [site No. 9]. The south eastern part of Spain is amongst the most intensely mineralised regions of Europe, with a great variety of ore-forming environments containing primarily $\mathrm{Pb}-\mathrm{Zn}-\mathrm{Ag}$ ores whereas $\mathrm{Cd}$ is found as an impurity ${ }^{41}$. Cadmium inputs at these sites, a part from the geological nature of the soils in the mining districts, could show some influence from domestic inputs and industrial areas. The potential contributions through atmospheric emissions from a huge nearby coal-based power plant located near Cabo de Gata (Carboneras) and from the industrial area of Cartagena-Escombreras should be also considered. In Italy, Portoscuso [site No. 99] is a high environmental risk area ${ }^{42}$ due to pollution from the Portovesme industrial zone and the Iglesiente-Sulcis mining district. Although most mines were closed in 1980-1990, residues of mining exploitation and processing have been left on site and they may cause heavy-metal pollution in the aquatic system ${ }^{43}$. High levels of $\mathrm{Pb}$ and $\mathrm{Cd}$ in accordance with earlier reported concentrations in sediments and caged mussels were found in this area ${ }^{19,44}$. On the north Sardinian coast, the industrial harbour of Porto Torres [site No. 101] recorded 
high levels of $\mathrm{Cd}, \mathrm{Pb}$ and $\mathrm{Ni}$ which are concordant with the metal levels in mussels and Posidonia oceanica reported by Lafabrie ${ }^{22,45}$.

Other high $\mathrm{Pb}$ levels were found in Spain at Cabo de Palos [site No. 13] which may be the result of the resuspension of the contaminated sediments of the adjacent site of Portman, during storm events and Palma de Mallorca [site No. 21] potentially due to harbour dredge activities, high maritime traffic and wastewaters discharges. On the Italian littoral, the high level of $\mathrm{Pb}$ at Oristano [site No. 100] is concordant with the high trace metals concentrations reported in sediments ${ }^{46}$ and in resident mussels ${ }^{47}$ possibly related with the processing plants of bentonite and perlite. It is worth to mention, the high $\mathrm{Pb}$ level found in Nador [site No. 120], along the Moroccan coast, considered a hot spot ${ }^{48}$, were in agreement with the $\mathrm{Pb}$ values reported in brown mussels (Perna perna) by Banaoui et al. ${ }^{49}$. Within the Alboran sub-basin, the high levels of Cd at Torrox [site No. 5] and Cap de Trois Fourches in Morocco [site No. 122] seem related to domestic discharges, although the proximity of these three sites to the Strait of Gibraltar with the potential contribution of Cd-enriched Spanish shelf water from the Atlantic Ocean and the drainage of the Iberian pyrite belt into the Gulf of Cadiz, should not be ignored ${ }^{50}$.

The evaluation of the potential sources of $\mathrm{Ni}$ and $\mathrm{Hg}$ point out to the anthropogenic activities as a major cause of its environmental occurrence. The highest levels of $\mathrm{Hg}$ in the North African coastal waters were measured in two Algerian sites highly populated and with huge petrochemical industry: Skkida [site No. 113] and Alger [sites No. 117 and 118]. The level of $\mathrm{Hg}$ at Alger bay is concordant with the results in sediments reported by Rouibah et al. ${ }^{51}$ and the level found at Skkida is in agreement with the high metals levels found by Gueddah and Djebar ${ }^{52}$. A substantial number of sites located on the Italian north-west coast of the Tyrrhenian Sea shown high levels of $\mathrm{Hg}$. The high $\mathrm{Hg}$ level at Piombino [site No. 72] is concordant with the results obtained by Bocchetti et al. ${ }^{53}$ at Piombino harbour, relating these high values to the industrial activities, combustion processes of the thermoelectric energy plants and dredging and disposal operations conducted in the area. Trace elements released by fuel combustion in the thermoelectric power plant have been previously related to the high level of $\mathrm{Hg}$ at Montalto di Castro [site No. 77] ${ }^{54}$. The very high level at La Maddalena Island [site No. 102] (Sardinia) appears to be linked to the existence of a naval base and an army shipyard. The maximum Hg value found at Palerme (Sicily) [site No. 93] is concordant with the metal levels in sediments reported by Tranchina et al. ${ }^{55}$ who relates the pollution sources to industrial, domestic wastes, harbour areas and river inputs. Nickel in the Tyrrhenian sub-basin (IV) show a ubiquitous pattern along the Tunisian coastal waters with peak levels at Tabarka [site No. 111] and La Galite Islands [site No. 110] and high levels at Korbous [site No. 106], Sidi Ali [site No. 108], Sidi Daoud [site No. 105] and Rades [site No. 107]. Our results are in agreement with a preliminary assessment of Pirrone et al. ${ }^{56}$, who studied past and current emissions of $\mathrm{Ni}$ to the atmosphere from major anthropogenic sources (e.g. fossil fuel consumption) in the Mediterranean. On the contrary, our results are far from the low $\mathrm{Ni}$ concentrations in the superficial sediments from the Gulf of Tunis ${ }^{57}$. The remaining North African coastal values are in agreement with previous research ${ }^{52,58,59}$. The maximum concentration of $\mathrm{Ni}$ at Orán [site No. 119] is in agreement with the high trace metal levels and biological effects in mussels ${ }^{60,61}$. Finally, high Ni concentrations were found on the coast of Italy (Genova-Cornigliano [site No. 67] and Livorno [site No. 71]) in agreement with previous studies using caged mussels ${ }^{22,23}$, potentially associated with industrial areas (e.g. steel industry) and harbours.

The main contributions of direct river inputs were also identified in the present study. Along the coast of France, mussels moored in the mouth of Huveaune river [site No. 47], currently considered to represent a significant source of trace metals into the 
Marseille gulf ${ }^{62}$, showed high $\mathrm{Pb}$ levels. The high level of $\mathrm{Hg}$ at Hyères Bay [site No. 50] (France), near the mouth of the small river Gapeau, could be also related to sewage inputs. Likewise, high $\mathrm{Pb}$ concentrations measured in the mouth of Llobregat river [site No. 35] (NE Spain) may be explained by the influence of the Barcelona metropolitis ${ }^{63}$. Nickel discharges in the Rhône site [site No. 46] were even higher than the values previously reported by Andral et al. ${ }^{33}$.

\subsection{Undefined sources of metal pollution in the Western Mediterranean Sea}

Remarkably, unexpected results were obtained in some coastal sites where there is not a known direct anthropogenic influence. Cadmium and lead pollution in some coastal locations in the Balearic Islands can not be directly attributed to known sources, such as, the level of $\mathrm{Cd}$ at Mahón [2.39 $\mathrm{mg} / \mathrm{Kg} \mathrm{dw}$; site No. 29], higher than previously reported by Deudero et al. ${ }^{64}$ in cultivated mussels, which suggested could be related to the costume jewellery industry or the high levels of $\mathrm{Pb}$ and $\mathrm{Cd}$ at Santa Eulalia [2.1 and $2.09 \mathrm{mg} / \mathrm{Kg} \mathrm{dw}$., respectively; site No. 19] which suggested it might be related to tourism activity. Even more, the reasons for the peak of $\mathrm{Ni}$ at Fornells $[1.2 \mathrm{mg} / \mathrm{Kg} \mathrm{dw}$.; site No. 30], the high values of $\mathrm{Pb}$ and $\mathrm{Cd}$ at Cala Treboluya [2.0 and $2.16 \mathrm{mg} / \mathrm{Kg} \mathrm{dw}$.; site No. 28], and the high level of $\mathrm{Cd}$ at Cabrera [2.58 mg/Kg dw.; site No. 22], are difficult to explain and may be considered as natural levels due to the low degree of impact of human activities. The oxidative stress biomarkers determined in caged mussels deployed at these sites showed the absence of biological effects associated with the chemical pollution ${ }^{65}$, therefore suggesting natural levels. Several authors suggested that Balearic Islands are under a marked influence of long range transport of atmospheric aerosols and Saharan dust ${ }^{66,67}$, but either natural or local anthropogenic sources could not be discarded at present. The high levels of Cd at Ustica [site No 94] and Filicude [site No. 91] (Sicily) might be mainly justified by the geological nature of substrata, since these islands constitute the emerged part of a volcanic complex. Although our results at Ustica agree with the high trace metals levels in sediments reported by Perra et al. ${ }^{68}$, further studies are needed to support this assumption. On the other hand, the concentration of Ni measured in Morocco at Nador $[2.72 \mathrm{mg} / \mathrm{kg} \mathrm{dw}$.; site No. 120] has not been previously reported in the literature and should be further studied locally. A very high $\mathrm{Ni}$ input into the Mediterranean was also found in Algeria at the mouth of Zhour [3.1 mg/Kg dw.; site No. 114] which seems to be more related to the high heavy mineral content of beach and dune sands ${ }^{69}$.

Despite the high levels of certain trace metals found in coastal waters were already identified as anthropogenic hot spots or priority pollution sensitive areas in the Western Mediterranean Sea ${ }^{70}$, natural processes, namely, land erosion, run-off, upwelling, atmospheric deposition, could also lead to enhanced natural concentrations of some metals in coastal areas. Consequently, the assessment of potentially contaminated sites depends on the significance of both sources and the measured metal contents do not automatically imply contamination (or pollution), because site-specific high concentrations may represent entirely natural conditions. Additional research efforts are needed in order to distinguish between the anthropogenic or natural origin of metal sources (e.g. isotopic studies). 


\subsection{Comparative assessment of metal pollution in the Western Mediterranean Sea}

The non-adjusted data and previous reported datasets available for caged mussels, from various marine environments elsewhere are shown in Table 1. Previous $\mathrm{Pb}$ levels reported in the Mediterranean and Atlantic coasts of France ${ }^{71,72}$ were similar or even lower than mean $\mathrm{Pb}$ concentration found in this study $\left(1.41 \mathrm{mg} \mathrm{kg}^{-1} \mathrm{dw}\right)$. Higher levels have been reported for polluted areas of singular sites of the NW Italy ${ }^{19,}{ }^{21}$, Scheldt estuary ${ }^{73}$, San Francisco bay ${ }^{74}$, and Hong Kong waters ${ }^{16}$. The $\mathrm{Cd}$ concentrations found were slightly higher than the mean $\left(1.32 \mathrm{mg} \mathrm{kg}^{-1} \mathrm{dw}\right)$ compared to most of the published data but lower compared to highly polluted areas such as SW of Sardinia ${ }^{19}$ and San Francisco Bay. The $\mathrm{Hg}$ values where within the range measured on the Mediterranean and Atlantic coasts of France and the mean concentration $\left(0.10 \mathrm{mg} \mathrm{kg}^{-1}\right.$ $\mathrm{dw}$ ) was lower than elsewhere, except for the high value at San Francisco Bay. The Nickel mean concentration (1.10 $\mathrm{mg} \mathrm{kg}^{-1} \mathrm{dw}$ ) was much lower than the values found in the polluted areas localised in the Mediterranean French coast ${ }^{71}$, Sardinia ${ }^{19}$ and Scheldt estuary ${ }^{73}$. Only trace metals levels measured at off-shore areas of the German Bight and Statfjord in the North Sea ${ }^{20}$ were lower than the levels obtained in our study. Finally, from an ecotoxicological perspective, the metal concentrations determined are below the maximum levels set by EU (Commission Regulation (EC) No. 1881/2006) in shellfish with respect to their human health risk, with the only exception for $\mathrm{Hg}$ in Portoscuso [site No. 99] (Sardinia).

\section{Conclusions}

The geographical coverage of the sampling (i.e. ABM approach) and the location of the sites within the dilution zone of the land based sources have made possible to gain significant knowledge about the trace metal contamination $(\mathrm{Hg}, \mathrm{Ni}, \mathrm{Pb}$ and $\mathrm{Cd})$, biogeochemistry, sources and levels in the Western Mediterranean basin, as well as to identify hot spots and new areas of concern. Few sites with high metal concentrations could not be linked to known anthropogenic activities and requires further investigation (e.g. Balearic Islands). High metal concentrations were predominantly found at sites closed to mining, industrial and/or urban areas. The following general conclusions may be drawn: higher Cd levels in coastal waters of the Alborán Sea (sub-basin I); higher chemical pressure by $\mathrm{Pb}$ in the West and Northwestern Mediterranean coast (subbasins I and II); higher $\mathrm{Hg}$ levels in coastal waters of the Tyrrhenian Sea (sub-basin IV); and a predominance of high Ni levels along the North Africa coast; whilst the rest of the Western Mediterranean confirm moderate to low levels of metal pollution (based on the datasets from this study). The standard ABM approach applied in the present study is a relatively easy tool for making a large scale assessment of the chemical water quality among different geographic regions. 


\section{Acknowledgements}

The authors wish to thank to Dr. E. Lahdes (Finnish Institute of Marine Research) and Dr. A.D. Vethaak (Deltares/VU University Amsterdam), for their scientific advice. We also thank C. Tomasino, E. Emery, H. Gilles, and C. Ravel, from IFREMER, and J. Guerrero, from IEO, for their technical assistance. This research was supported by EEC (Interreg/MedoccIIIB/MYTILOS Project). INRH (Morocco), ESSMAL (Algeria) and INSTM (Tunisia) were supported by UNEP MEDPOL Program.

\section{Supplementary material}

Table S1 shows the background information on geographical positions, code, site description, bottom depth, condition index values and the adjusted and raw concentrations of each metal analysed in the sampling sites. Figure S1 display the $\mathrm{Cl}$ in caged mussels from the four sub-basins of the Western Mediterranean sea $(N=123)$. Figure S2 shows the correlation between metal concentration and $1 / \mathrm{Cl}$ for $\mathrm{Pb}, \mathrm{Cd}, \mathrm{Hg}$ and $\mathrm{Ni}$ datasets and the linear regression model parameters. Figure S3 display the Log-normal frequency distribution curves of adjusted metal concentrations ( $\mathrm{Cd}, \mathrm{Hg}$ and $\mathrm{Ni}$ ) and $\mathrm{Pb}$ concentrations.

\section{References}

1 B.S. Halpern, K.A. Selkoe, F. Micheli and C.V. Kappel, Conserv. Biol., 2007, 21, 1301-1315.

2 D.J. Hoffman, B.A. Rattner, G.A. Burton and J. Cairns, Handbook of Ecotoxicology, $2^{\text {nd }}$ ed. CRC Press, Boca Raton, 2003.

3 R. Martí-Cid, A. Bocio, J.M. Llobet and J.L. Domingo, Food Chem. Toxicol., 2007, 45, 1968-1974.

4 UNEP/FAO/WHO. Assessment of the state of pollution of the Mediterranean Sea by cadmium and cadmium compounds. MAP Tech Rep Ser 34, 1989.

5 UNEP. The State of the Marine and Coastal Environment in the Mediterranean Region, MAP Tech. Rep. Ser. 100, 1996.

6 EEA, European Environment Agency, 2006. Priority issues in the Mediterranean environment. EEA Report No. 4.

http://www.eea.europa.eu/publications/eea report 20064 (accessed on the 22nd November 2010)

7 WFD, 2000. Water Framework Directive (2000/60/EC) European Commission. http://ec.europa.eu/environment/water/water-framework/index en.html (accessed on the 22nd November 2010) 
8 MSD, 2008. Marine Strategy Framework Directive (Directive 2008/56/EC). European Comission. http://ec.europa.eu/environment/water/marine/index en.htm (accessed on the 22nd November 2010)

9 E.D. Goldberg, Mar. Pollut. Bull., 1975, 6, 111-117.

10 L. Jeftic, M. Bernhard, A. Demetropoulos, F. Femex, G.P. Gabrielides, F. Gasparovic, Y. Halim, D. Orhon and L. Saliba, State of the Marine Environment in the Mediterranean Region, MAP Tech. Rep. Ser. 28, 1990.

11 G. Roesijadi, J.S. Young, A.S. Drum and J.M. Gurtisen, Mar. Ecol. Prog. Ser., 1984, 18, 155-170.

12 D.J.H. Phillips and P.S. Rainbow. Biomonitoring of trace aquatic contaminants. Environmental Management Series, ed. Chapman and Hall, 1993, London.

13 M. Schulz-Baldes. Mar. Biol., 1974, 25, 177-193.

14. S. Casas and C. Bacher. J. Sea. Res., 2006, 52, 168-181

15 M. Ali and A. Taylor. Mesopot.J.Mar.Sci., 2010, 25, 11-30

16 H.M. Chan, Mar. Pollut. Bull., 1989, 20, 82-86.

17 W.C. De Kock and K.J.M. Kramer, in Biomonitoring of coastal waters and estuaries, ed. K.J.M. Kramer, CRC Press, Boca Raton, 1994, pp. 51-84.

18 M. Romeo, P. Hoarau, G. Garello, M. Gnassia-Barelli and J.P. Girard, Environ. Pollut., 2003, 122, 369-378.

19 M. Schintu, L. Durante, A. Maccioni, P. Meloni, S. Degetto and A. Contu, Mar. Pollut. Bull., 2008, 57, 832-837.

20 A. Ruus, K.E. Tollefsen, M. Grung, J. Klungsoyr and K. Hylland, in Biological Effects of Contaminants in Marine Pelagic Ecosystems. K.T. Hylland, T. Lang and A.D. Vethaak eds. Society of Environmental Toxicology and Chemistry (SETAC), 2006, pp. 51-74.

21 G. Frenzilli, R. Bocchetti, M. Pagliarecci, M. Nigro, F. Annarumma, V. Scarcelli, D. Fattorini and F. Regoli, Mar. Environ. Res., 2004, 58, 609-613.

22 C. Lafabrie, G. Pergent, R. Kantin, C. Pergent-Martini and J.L. Gonzalez, Chemosphere, 2007, 68, 2033-2039.

23 P. Rivaro, M.L. Abelmoschi, R. Leardi and R., Frache, Toxicol. Environ. Chem., 2000, 75, $99-111$.

24 D. Cossa, Oceanol. Acta., 1989, 12, 417-432.

25 O. Maire, J.M. Amouroux, J.C. Duchene and A. Gremare, Mar. Biol., 2007, 152, 1293-1307. 
26 K.R. Freeman, Growth, mortality and seasonal cycle of Mytilus edulis in two Nova Scotia embayments. Department of Environment, Fisheries and Marine Service, Canada, Tech. Rep. No. 500, 1974, pp.1-112.

27 P.B. Lobel and D.A. Wright, Mar. Biol., 1982, 66, 145-150.

28 J.M. Capuzzo, J.W. Farrigton, P. Rantamaki, C.H Offord, B.A. Lancaster, D.F Leavitt and X. Jia, Mar. Environ. Res., 1989, 28, 259-264.

29 M. Soto, M. Kortabitarte and I. Marigomez, Mar. Ecol. Prog. Ser., 1995, 125, 127136.

30 R.S.S. Wu, T.C. Lau, W.K.M. Fung, P.H. Ko and K.M.Y. Leung, Environ. Pollut., 2007, 145, 104-110.

31 K.M.Y. Leung, R.W. Furness, J. Svavarsson, T.C. Lau and R.S.S. Wu, Mar. Pollut. Bull., 2008, 57, 6-12.

32 T. Borchardt, S. Burchert, H. Hablizel, L. Karbe and R. Zeitner, Mar. Ecol. Prog. Ser., 1998, 42, 17-31.

33 B. Andral, J.Y. Stanisiere, D. Sauzade, E. Damier, H. Thebault, F. Galgani and P. Boissery, Mar. Pollut. Bull., 2004, 49, 704-712.

34 F. Galgani, C. Martínez-Gómez, F. Giovanardi, G. Romanelli, J. Caixach, A. Cento, A. Scarpato, S. BenBrahim, S. Messaoudi, S. Deudero, M. Boulahdid, J. Benedicto and B. Andral, Environ. Monit. Assess., 2010, DOI 10.1007/s10661-010-1335-5

35 A. Scarpato, G. Romanelli, F. Galgani, P. Giordano, B. Andral, M. Amici, M. Calvo, J. Caixach, J.A. Campillo, J. Benedicto, A. Cento, B. Benbrahim, C. Sammari, S. Deudero, M. Boulahdid and F. Giovannardi, J. Environ. Monit., 2010, 12, 924 - 935.

36 T.P. O'Connor, 1992. Recent trends in coastal environmental quality: Results from the first five years of the NOAA Mussel Watch Project. U.S. Dept. of Commerce, National Oceanic and Atmospheric Administration, National Ocean Service, Rockville, Maryland. Available from: <http://www.archive.org/details/musselwatchrecen00ocon> (accessed on the 22nd November 2010)

37 J. Martínez-Frías, Nature, 1997, 388, 120.

38 J. Benedicto, C. Martínez-Gómez, J. Guerrero, A. Jornet and C. Rodríguez, Cien. Mar., 2008, 34, 389-398.

39 C. Sanchiz, A.M. García-Carrascosa and A. Pastor, Mar. Ecol., 2000, 21, 1-16.

40 C. Rodríguez, J. Guerrero, J. Benedicto and A. Jornet, $34^{\text {th }}$ CIESM Congress Proceedings, No. 34, 1995, pp. 145.

41 M. Sierra, Niveles de metales y elementos asociados en suelos de la Provincia de Almería. Parámetros que los afectan y riesgos de contaminación. PhD Thesis. Universidad de Granada, 2005.

42 F. Mitis, M. Martuzzi, A. Biggeri, R. Bertollini and B. Terracini, Int. J. Occup. Environ. Health., 2005, 11, 88-95. 
43 R. Cidu and L. Fanfani, Geochemistry: Exploration, Environment, Analysis, 2002, 2, 243-251.

44 M. Schintu and S. Degetto, Sci. Total Environ., 1999, 241, 129-141.

45 C. Lafabrie, G. Pergent and C. Pergent-Martini, Sci. Total Environ., 2009, 407, 2440-2446.

46 A. Cucco, A. Perilli, G. De Falco, M. Ghezzo and G. Umgiesser, Chemistry and Ecology, 2006, 22, S307-S331.

47 P. Magni, G. De Falco, C. Falugi, M. Franzoni, M. Monteverde, E. Perrone, M. Sgro and C. Bolognesi, Environ. Pollut., 2006, 1, 65-72.

48 Y. Sabhi, M. Chaoui, S. El Quessar, S. Bakkas and M. Ramdani, Bulletin de I'Institut Scientifique, Rabat, 1999-2000, 22, 59-69.

49 A. Banaoui, J.F. Chiffoleau, A. Moukrim, T. Burgeot, A. Kaaya, D. Auger and E. Rozuel, Mar. Pollut. Bull., 2004, 48, 385-390.

50 F. Elbaz-Poulichet, C. Guieu and N.H. Morley, Mar. Pollut. Bull., 2001, 42, 623-627.

51 M. Rouibah, M. Boulahdid, B. Boudejellal, N. Eddalia and F. Ounadi, Etude de la pollution du littoral Algerois et du lac de Reghaia, 2005. Agence pour la Protection et de la Promotion du Littoral Algérois (APPL). Available from: http://www.appl.dz/spip.php?article215 (accessed on the 22nd November 2010)

52 D. Gueddah and A.B. Djebar, Mesogee, 2006, 62, pp. 21.

53 R. Bocchetti, D. Fattorini, B. Pissanelli, S. Macchia, L. Oliviero, F. Pilato, D. Pellegrini and F. Regoli, Aquat. Toxicol., 2008, 89, 257-266.

54 N. Violante, O. Senofonte, G. Marsili, P. Meli, M.E. Soggiu and S. Caroli, Microchem. J., 2000, 67, 397-405.

55 L. Tranchina, S. Basile, M. Brai, A. Caruso, C. Cosentino and S. Miccichè, Water Air Soil Pollut., 2008, 191, 245-256.

56 N. Pirrone, P. Costa and J.M. Pacyna, Water Sci. Technol., 1999, 39, 1-7.

57 A. Added, A. Ben Mammou, S. Abdeljaoued, N. Essounni and F. Fernex, Bulletin de I'Institut National des Sciences et Technologies de la Mer, Salammbô, 2003, 30, 135142.

58 H. Beldi, F. Gimbert, S. Maas, R. Scheifler and N. Soltani, Afr. J. Agric. Res., 2006, 1, 85-90.

59 M. Kehal, A. Mennour, L. Reinert and H. Fuzellier, Environ. Technol., 2004, 25, 1059-1065.

60 Z. Boutiba, M.Z. Taleb, S.M., Abi Ayad, and A. El. Etat de la pollution marine de la côte oranaise, ed. Dar El Gharb, Oran, 2003. 
61 Z.M. Taleb, I. Benali, H. Gherras, A. Ykhlef-Allal, D. Bachir-Bouiadjra, J.C. Amiard and Z. Boutiba, Oceanologia, 2009, 51, 63-84.

62 D. Sauzade, B. Andral, J.L. Gonzalez, F. Galgani, C. Grenz, H. Budzinski, A. Togola and S. Lardy, Synthèse de l'état de la contamination chimique du golfe de Marseille. Convention Ifremer/Agence de l'Eau Rhône Méditerranée et Corse $n^{\circ}$ 802.2004.058, 2007, pp. 123. Available from: http://sierm.eaurmc.fr/rlm/outilsmethodologiques/documents/07-05-Metrocvol1-VD.pdf (accessed on the 22nd November 2010)

63 A. Palanques, P., Masqué, P., Puig, J.A. Sánchez-Cabeza, M. Frignani and F. Alvisi, Mar. Geol., 2008, 48, 213-227.

64 S. Deudero, A. Box, D. March, J.M. Valencia, A. Grau, J. Tintore and J. Benedicto, Mar. Pollut. Bull. , 2007, 54, 1545-1588.

65 A. Box, A. Sureda, F. Galgani, A. Pons and S. Deudero, Comp. Biochem. Physiol. C., 2007, 146, 531-539.

66 J. Mateu, F. Bauzá de Mirabó, R. Forteza, V. Cerdá, M. Colom and M. Oms, Water Air Soil Pollut., 1999, 112, 349-363.

67 A. Tovar-Sánchez, J. Serón, N. Marbà, J.M. Arrieta and C.M. Duarte, J. Geophys. Res., 2010, 115, DOI 10.1029/2009jg001076.

68 G. Perra, K. Pozo, C. Balocchi, V. Menchi, D. Lazzeri, S. Corsolini and S. Focardi, SETAC Europe $13^{\text {th }}$ Annual Meeting, Abstracts Book TUP/16, 2003.

69 A. Bouzenoune and K. Remoum, Bulletin du Service Géologique National, 2008, 19, $287-302$.

70 UNEP. Strategic Action Programme. Second report on the pollution hot spots in the Mediterranean, Part I: Country results, 2003; UNEP(DEC)/MED WG.231/5a.

71 B. Andral, J.Y. Stanisiere, D. Sauzade, Y. Henocque, H. Thebault and P. Boissery, $35^{\text {th }}$ CIESM Congress Proceedings, pp. 35, 1992.

72 M.H. Devier, S. Augagneur, H. Budzinski, K. Le Menach, P. Mora and J.F. Narbonne, J Environ. Monit., 2005, 7, 224-240.

73 V. Wepener, L. Bervoets, V. Mubiana and R. Blust,. Mar. Pollut. Bull., 2008, 57, 624-631.

74 D.R. Smith, M.D. Stephenson and A.R. Flegal, Environ. Toxicol. Chem., 1986, 5, 129-138. 


\section{Figures}

Figure 1: Sampling sites along the Western Mediterranean Sea (sub-basins: I= Alborán; II= North-Western; III= South-Western; IV= Tyrrhenian). Site codes, names and descriptions are provided in Supplementary Material.

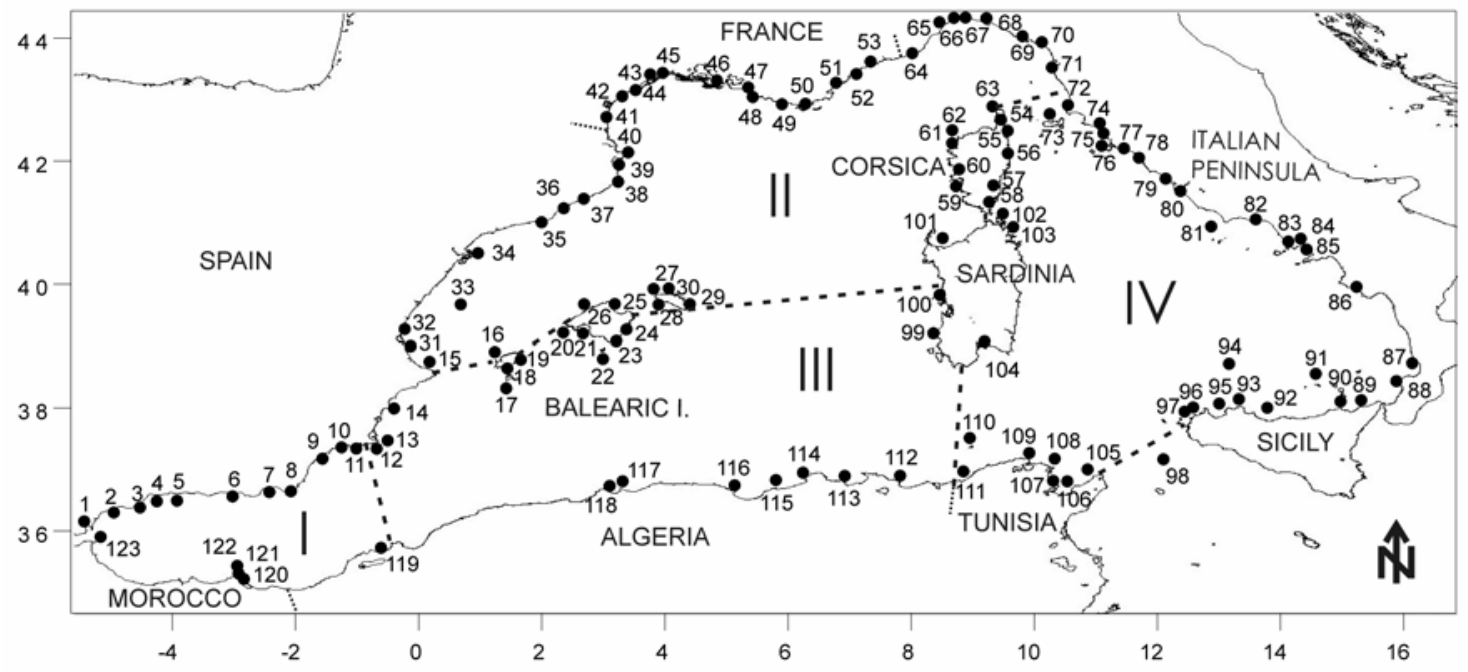


Figure 2: Raw and adjusted metal concentrations ( $\mathrm{Cd}, \mathrm{Ni}, \mathrm{Hg}$ and $\mathrm{Pb}$ ) in Mytilus galloprovincialis at the 123 sampling sites along the near-shore coastal waters Western Mediterranean region. Full data is available in Supplementary Meterial.
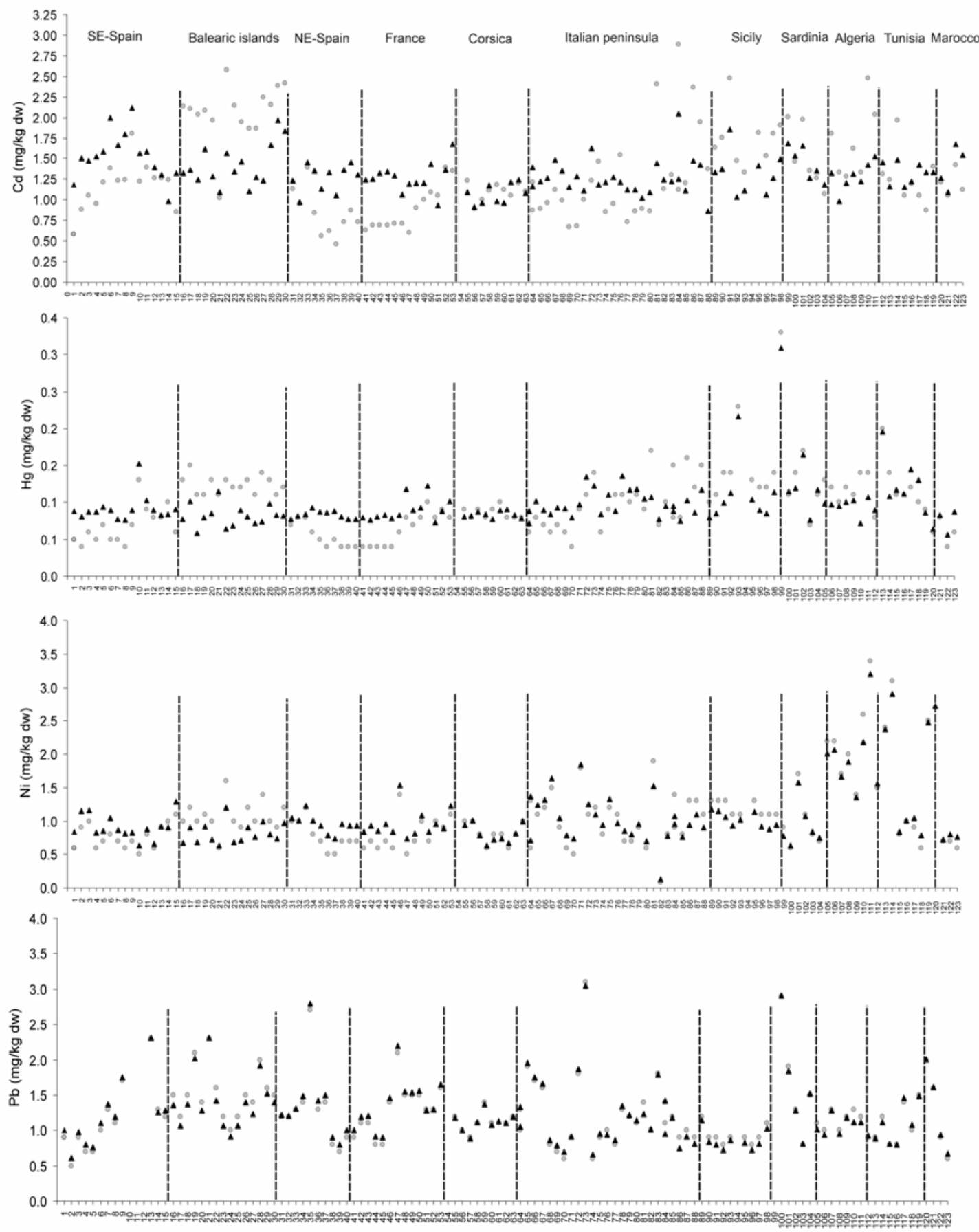

Figure 3: Spatial distribution of the adjusted concentrations of lead (A), cadmium (B), mercury $(C)$ and nickel $(D)$ in the Mediterranean sub-basins (I= Alborán; II= NorthWestern; III= South-Western; IV= Thyrrenian). Upper left legend show the concentration ranks for each metal. 

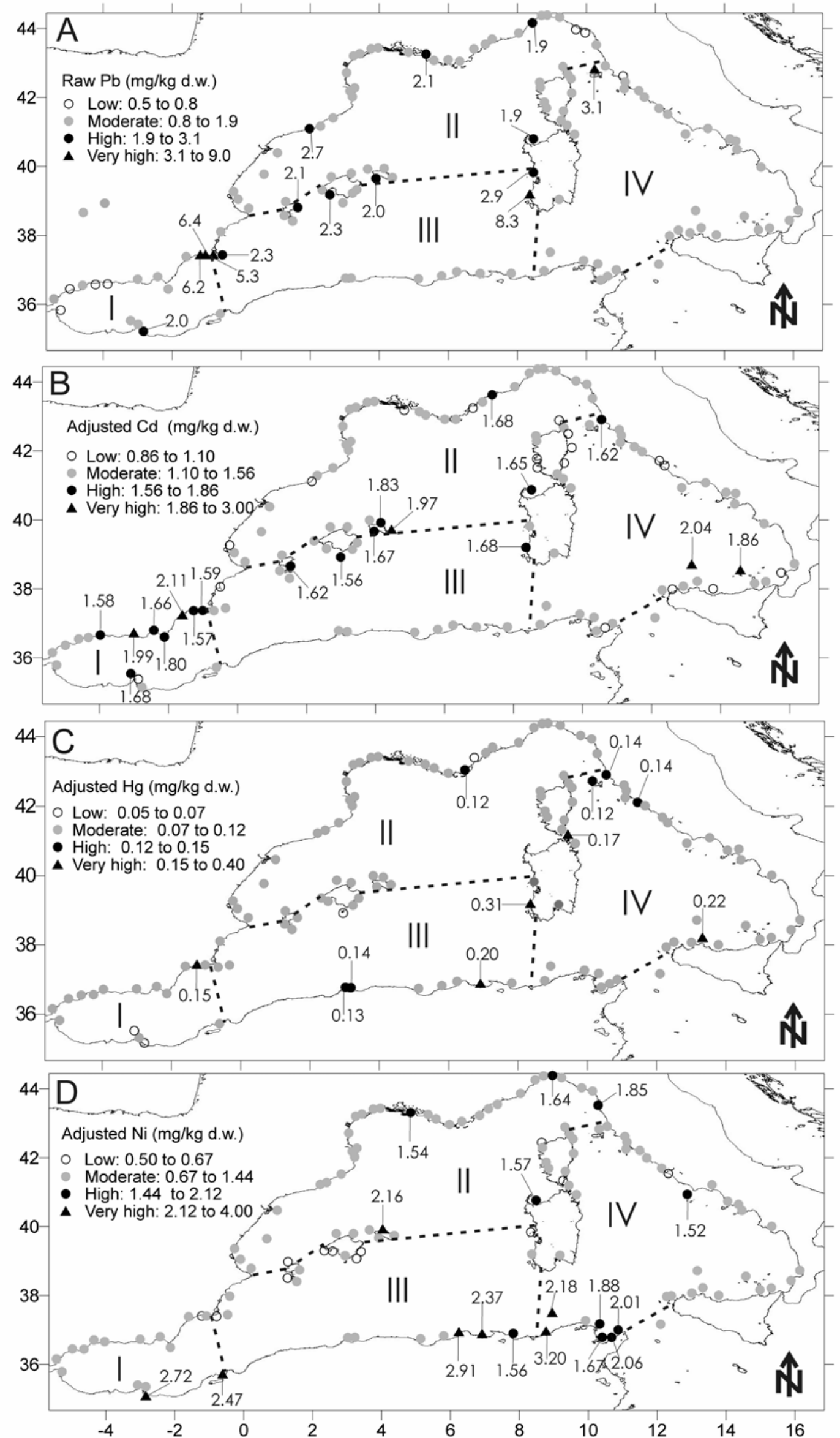
Tables

Table 1. Mean \pm SD and range (min-max) of trace metal concentrations ( $\mathrm{mg} \mathrm{kg}^{-1} \mathrm{dry}$ weight) in caged mussels (Mytilus galloprovincialis). ${ }^{a}$ Range of mean values; ${ }^{b}$ Mytilus edulis; ${ }^{\mathrm{c}}$ Mytilus californianus; ${ }^{\mathrm{d}}$ Perna viridis

\begin{tabular}{|c|c|c|c|c|c|c|c|c|c|c|}
\hline Study areas & Years & $\mathrm{N}$ & $\begin{array}{l}\text { Time } \\
\text { exposure }\end{array}$ & of & Shell length & $\mathrm{Pb}$ & $\mathrm{Cd}$ & $\mathrm{Hg}$ & $\mathrm{Ni}$ & Reference \\
\hline Western Mediterranean (WM) & $2004-2006$ & 123 & 3 months & May-July & $50 \pm 5 \mathrm{~mm}$ & $\begin{array}{l}1.4 \pm 0.1 \\
(0.5-8.3)\end{array}$ & $\begin{array}{l}1.33 \pm 0.52 \\
(0.46-2.89)\end{array}$ & $\begin{array}{l}0.10 \pm 0.04 \\
(0.04-0.33)\end{array}$ & $\begin{array}{l}1.1 \pm 0.6 \\
(0.1-3.4)\end{array}$ & Present study \\
\hline WM-Alborán sub-basin (I) & $2004-2006$ & 16 & 3 months & May-July & $50 \pm 5 \mathrm{~mm}$ & $\begin{array}{l}1.75 \pm 1.8 \\
(0.5-6.4)\end{array}$ & $\begin{array}{l}1.20 \pm 0.28 \\
(0.58-1.81)\end{array}$ & $\begin{array}{l}0.06 \pm 0.02 \\
(0.04-0.13)\end{array}$ & $\begin{array}{l}0.9 \pm 0.7 \\
(0.5-2.7)\end{array}$ & Present study \\
\hline WM-North-Western sub-basin (II) & $2004-2006$ & 45 & 3 months & May-July & $50 \pm 5 \mathrm{~mm}$ & $\begin{array}{l}1.3 \pm 0.4 \\
(0.6-2.7)\end{array}$ & $\begin{array}{l}1.11 \pm 0.52 \\
(046-2.42)\end{array}$ & $\begin{array}{l}0.08 \pm 0.03 \\
(0.04-0.14)\end{array}$ & $\begin{array}{l}0.9 \pm 0.3 \\
(0.5-1.8)\end{array}$ & Present study \\
\hline WM-South-Western sub-basin (III) & $2004-2006$ & 20 & 3 months & May-July & $50 \pm 5 \mathrm{~mm}$ & $\begin{array}{l}1.9 \pm 1.8 \\
(0.8-8.3)\end{array}$ & $\begin{array}{l}1.60 \pm 0.49 \\
(0.87-2.58)\end{array}$ & $\begin{array}{l}0.13 \pm 0.05 \\
(0.08-0.33)\end{array}$ & $\begin{array}{l}1.1 \pm 0.6 \\
0.6-3.1\end{array}$ & Present study \\
\hline WM-Tyrrhenian sub-basin (IV) & $2004-2006$ & 42 & 3 months & May-July & $50 \pm 5 \mathrm{~mm}$ & $\begin{array}{l}1.1 \pm 0.4 \\
(0.6-3.1)\end{array}$ & $\begin{array}{l}1.1 .47 \pm 0.52 \\
(0.73-2.89)\end{array}$ & $\begin{array}{l}0.12 \pm 0.03 \\
(0.06-0.23)\end{array}$ & $\begin{array}{l}1.1 \pm 0.6 \\
(0.8-3.4)\end{array}$ & Present study \\
\hline France-Mediterranean coast & 1996 & 84 & 5 months & February-July & $30-60 \mathrm{~mm}$ & $\begin{array}{l}1.35 \\
(0.3-1.9)\end{array}$ & $\begin{array}{l}1.11 \\
(0.3-2.7)\end{array}$ & $\begin{array}{l}0.123 \\
(0.05-0.19)\end{array}$ & $\begin{array}{l}1.16 \\
(0.2-4.5)\end{array}$ & Andral et al. (1998) \\
\hline France-Bays of Nice and Cannes & $1999-2000$ & 9 & 1 month & October-October & $45 \pm 5 \mathrm{~mm}$ & & $0.53-1.01^{\mathrm{a}}$ & & & Romeo et al. (2003) \\
\hline France-Arcachon bay & 2001-2002 & 7 & 1 month & February-February & $40-50 \mathrm{~mm}$ & $1.4-1.6^{\mathrm{a}}$ & $0.8-1.0^{a}$ & & $1.1-1.5^{\mathrm{a}}$ & Devier el al. (2005) \\
\hline Italy-Sardinia & $\begin{array}{l}2004 \\
2005 \\
2006\end{array}$ & $\begin{array}{l}4 \\
4 \\
4\end{array}$ & $\begin{array}{l}1 \text { month } \\
1 \text { month } \\
1 \text { month }\end{array}$ & $\begin{array}{l}\text { February-March } \\
\text { August-September } \\
\text { January-February }\end{array}$ & $\begin{array}{l}50-60 \mathrm{~mm} \\
50-60 \mathrm{~mm} \\
50-60 \mathrm{~mm}\end{array}$ & $\begin{array}{l}5-18.2^{\mathrm{a}} \\
1.4-4.6^{\mathrm{a}} \\
1.5-7.4^{\mathrm{a}}\end{array}$ & $\begin{array}{l}0.50-2.84^{a} \\
0.17-0.45^{a} \\
0.85-1.03^{a}\end{array}$ & & $\begin{array}{l}4.5-15.0^{\mathrm{a}} \\
1.2-13.2^{\mathrm{a}} \\
1.5-6.1^{\mathrm{a}}\end{array}$ & Schintu et al. (2008) \\
\hline Italy-La Spezia and Genova harbour & 2001 & 1 & 4 weeks & June-July & $45 \pm 5 \mathrm{~mm}$ & $5.0-7.7^{\mathrm{a}}$ & $0.2-0.4^{a}$ & & & Frenzilli et al. (2004) \\
\hline Italy-Ligurian sea & 1995 & 8 & 3 weeks & March-October & $40-60 \mathrm{~mm}$ & & $0.14-0.67^{\mathrm{a}}$ & & $0.16-1.50^{\mathrm{a}}$ & Rivaro et al. (2000) \\
\hline Netherlands-Scheldt estuary ${ }^{\mathrm{b}}$ & 2000 & 1 & 6 weeks & March & $40-50 \mathrm{~mm}$ & $7.46 \pm 0.41$ & & & $15.86 \pm 1.54$ & Wepener et al. (2008) \\
\hline Southern North Sea-German Bight ${ }^{\mathrm{b}}$ & 2001 & 4 & 5-6 weeks & May-June & $40-50 \mathrm{~mm}$ & $\begin{array}{l}0.31 \\
(0.14-0.45)\end{array}$ & $\begin{array}{l}0.232 \\
(0.13-0.31)\end{array}$ & $\begin{array}{l}0.023 \\
(0.012-0.039)\end{array}$ & $\begin{array}{l}0.523 \\
(0.16-1.14)\end{array}$ & Ruus et al. (2005) \\
\hline North Sea-Statfjord ${ }^{\text {b }}$ & 2001 & 4 & 5-6 weeks & May-June & $40-50 \mathrm{~mm}$ & $\begin{array}{l}0.135 \\
(0.10-0.34)\end{array}$ & $\begin{array}{l}0.875 \\
(0.49-1.09)\end{array}$ & $\begin{array}{l}0.015 \\
(0.013-0.018)\end{array}$ & $\begin{array}{l}0.2275 \\
(0.18-0.34)\end{array}$ & Ruus et al. (2005) \\
\hline EEUU-San Francisco bay ${ }^{c}$ & 1980-1982 & 17 & 5.5-4 months & August & $45-65 \mathrm{~mm}$ & $0.78-8.70^{a}$ & $7.1-20.0^{\mathrm{a}}$ & $0.09-0.58^{\mathrm{a}}$ & & Smith et al. (1986) \\
\hline Hong Kong waters ${ }^{d}$ & $1986-1987$ & 4 & 1-13 months & Every month & $35-45 \mathrm{~mm}$ & $\begin{array}{l}10.9 \pm 2.73 \\
(4.10-24.1)\end{array}$ & $\begin{array}{l}1.10 \pm 0.56 \\
(0.03-3.29)\end{array}$ & & & Chan H.M. (1989) \\
\hline
\end{tabular}

